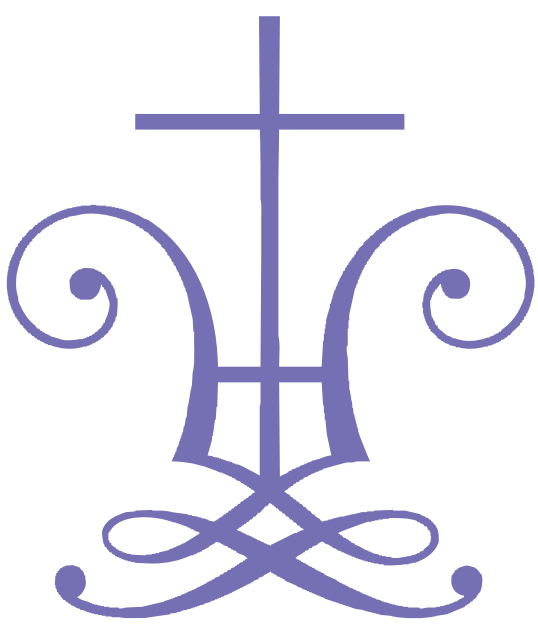

\title{
Journal of Theological Interpretation
}

\section{VOLUME 8 , NO. I $\bullet$ SPRING, 2OI4}

Kerygma and Community:

A Response to R. W. L. Moberly's Revisiting of Bultmann

DAVID W. CongDON

The Beginnings of a Theology of Luke-Acts:

Divine Activity and Human Response

JoshUA W. Jipp . .

"Nothing beyond What Is Written"? I Corinthians and the Hermeneutics

of Early Christian Theologia

David I. STARLING

Thomas Aquinas, 2 Corinthians 5 ,

and the Christian Hope for Life after Death

Jason Hentschel . .

Divine Ordinances and Life-Giving Remedies:

Galatians in the Writings of Cyprian of Carthage

Edwina Murphy

You Are Filled in Him:

Theosis and Colossians 2-3

Ben C. Blackwell

Paul's "Anti-Christology" in

2 Thessalonians 2:3-12 in Canonical Context

ANDY JoHnson . .

The Untold History of Modern

Biblical Scholarship's Pre-Enlightenment Secular Origins

JEFFREY L. MORROW 


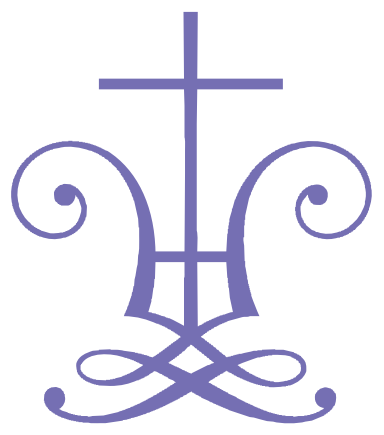

\title{
Journal of Theological Interpretation
}

\author{
EDITOR-IN-CHIEF \\ Joel B. Green
}

EDITORIAL BOARD

Hans Boersma (Regent College, Canada)

Richard S. Briggs (St. John's College-Durham University, England)

Stephen B. Chapman (Duke University Divinity School, USA)

A. Katharine Grieb (Virginia Theological Seminary, USA)

Myk Habets (Carey Baptist College and Graduate School, New Zealand)

Trevor Hart (St. Mary's College, University of St. Andrews, Scotland)

Nathan MacDonald (University of Cambridge, England)

John J. O'Keefe (Creighton University, USA)

Ben C. Ollenburger (Associated Mennonite Biblical Seminary, USA)

Angus Paddison (University of Winchester, England )

Murray Rae (University of Otago, New Zealand)

C. Kavin Rowe (Duke University Divinity School, USA)

Dan R. Stiver (Hardin-Simmons University, USA)

Marianne Meye Thompson (Fuller Theological Seminary, USA)

J. Ross Wagner (Duke University Divinity School, USA)

Correspondence and papers for submission should be directed to Prof. Joel B. Green, Fuller Theological Seminary, 135 N. Oakland Ave., Box 257, Pasadena, CA 91182; e-mail: jbgreen@fuller.edu. See inside back cover for information for contributors.

The fournal of Theological Interpretation (ISSN $1936-0843$ ) is published and distributed by Eisenbrauns, P.O. Box 275, Winona Lake, IN 46590 USA. E-mail: jti@eisenbrauns.com

Copyright $(2014$ by Eisenbrauns Inc. All rights reserved. 


\title{
Kerygma and Community: A Response to R. W. L. Moberly's Revisiting of Bultmann
}

\author{
David W. Congdon \\ IVP ACADEMIC
}

\begin{abstract}
In a $20 \mathrm{I} 2$ article, R. W. L. Moberly brought Bultmann into conversation with Augustine around the question of hermeneutical presuppositions. The article affirmed Bultmann's emphasis on "existential openness" but criticized his apparent disregard for the church as the primary presupposition for biblical interpretation. Moberly's article misreads Bultmann, however, and misses the deeper logic at work in Bultmann's apparent lack of attention to ecclesiology. The community, as the bearer of the kerygma, is included within the event that it proclaims. Ecclesiology is therefore indirectly present, so that, as Bultmann states regarding John, "one may not conclude from this that interest in the church-community is completely absent. On the contrary, there is a very lively interest in it." Key Words - Rudolf Bultmann, Christology, church, tradition, demythologizing, presuppositions, revelation, bistory
\end{abstract}

After decades of misunderstanding and misuse, we are beginning to see the rise of a new appreciation for the work of Rudolf Bultmann. Disparaged by both liberals and conservatives - and later by postliberals and postconservatives - his legacy is gaining a new hearing. ${ }^{\mathrm{I}}$ An example of this is Walter Moberly's fine piece on Bultmann and Augustine on the role of

Author's note: My thanks to Collin Cornell and Travis McMaken for reading an earlier version of this article.

I. Within English-speaking scholarship, key indications of a new appreciation include Christophe Chalamet, Dialectical Theologians: Wilhelm Herrmann, Karl Barth and Rudolf Bultmann (Zürich: TVZ, 2005); Benjamin Myers, "Faith as Self-Understanding: Towards a Post-Barthian Appreciation of Rudolf Bultmann," International fournal of Systematic Theology IO/I (2008): 21-35; William D. Dennison, The Young Bultmann: Context for His Understanding of God, I884-1925 (New York: Peter Lang, 2008); Tim Labron, Bultmann Unlocked (London: T. \& T. Clark, 20II). The most significant advances, however, are in German scholarship. This is largely because of the major effort currently ongoing to study and publish Bultmann's Nachlass. The most important fruit of this investigation of his archive is the groundbreaking biography by Konrad Hammann, Rudolf Bultmann: Eine Biographie (Tübingen: Mohr Siebeck, 2009), recently published in English (trans. Philip E. Devenish; Salem, OR: Polebridge, 20I2).

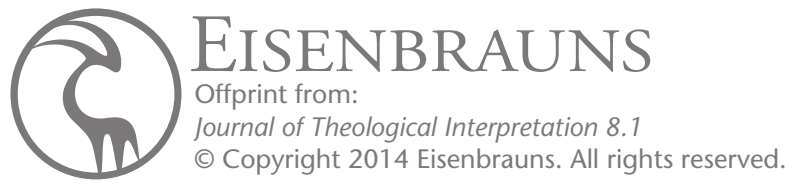


presuppositions and the church in the interpretation of Scripture. ${ }^{2}$ His aim in that article is to argue for the church as the presupposition for the interpretation of the Bible. Bultmann was correct, Moberly argues, to make presuppositions a necessary aspect of interpretation, but he failed to give any attention to the church as essential to the hermeneutical enterprise. He was blind to the role that his own Lutheran church community played in his theological development. Moberly seeks to correct Bultmann by way of Augustine's claim, "I would not believe the gospel if the authority of the Catholic Church did not move me." The church, according to Moberly, is the sociological "plausibility structure" within which the message of the Bible becomes credible and meaningful. The purpose of this response is to address the first half of the article on Bultmann. Although Moberly succeeds in avoiding most of the gross errors that still remain in circulation, the mistakes that remain are still sufficient to warrant a (friendly) rebuttal.

\section{Preunderstanding and Self-Understanding: The Presupposition of Faith}

I begin with some minor clarifications. First, Moberly's summary of Bultmann's 1957 essay "Is Exegesis without Presuppositions Possible?" is misleading and would seem to lend credence to the erroneous Barthian objection that Bultmann engages in a kind of natural theology of an existentialist variety. In reviewing the essay's five concluding theses regarding responsible exegesis, ${ }^{3}$ Moberly makes the understandable mistake of conflating Bultmann's position on general interpretation with his account of specifically Christian interpretation. The problem occurs in his summary of theses three and four, where he asks:

For if the subject matter of the Bible includes God, what kind of life relation to subject matter such as this is necessary? Must one, it might be asked, be a believer? ... Bultmann uses the language of faith only in the context of expounding his fourth thesis ... where faith is the result of, rather than the presupposition for, encounter of this sort. (p.3)

Moberly correctly points out that Bultmann does not make faith a precondition for the general understanding of historical texts, but nowhere does

2. R. W. L. Moberly, "Theological Interpretation, Presuppositions, and the Role of the Church: Bultmann and Augustine Revisited," Fournal of Theological Interpretation 6 (2012): I-22; hereafter cited parenthetically.

3. The five theses can be summarized as follows: (I) exegesis must be unprejudiced; (2) exegesis is not presuppositionless, because it presupposes historical-critical research; (3) exegesis presupposes a preunderstanding of the subject matter of the text; (4) this preunderstanding is open to new existential encounters and decisions; and (5) the understanding of the text is likewise never closed but always open. Rudolf Bultmann, "Ist voraussetzungslose Exegese möglich?" in Glauben und Verstehen: Gesammelte Aufsätze (4 vols.; Tübingen: Mohr Siebeck, I933-65; hereafter, Glauben und Verstehen), 3:142-50, here, pp. I48-49. 
Bultmann suggest that faith is then not a precondition for the specific understanding of the biblical text. And yet this is precisely the conclusion that Moberly draws when he later says, ostensibly in agreement with Bultmann, that "it is surely right to go along with Bultmann's refusal to depict the existential preunderstanding necessary for making sense of the Bible as belonging solely to those who operate within the categories of Christian faith" (p. 6, emphasis added). ${ }^{4}$ Moberly gives the impression that Bultmann's five theses are a complete statement of his biblical hermeneutics. This is understandable, because Bultmann uses the biblical text as his example in the essay. Unfortunately, it is an incomplete picture that has led many to conclude (incorrectly) that Bultmann views a genuine understanding of Scripture as a general human possibility. On Moberly's reading, it would seem that as long as one is "existentially open" to the text, one can rightly hear, understand, and respond to its claim on us.

In truth, Bultmann insists that faith is the sole basis and presupposition for understanding the message of the Bible. In his I940 lecture "The Question of Natural Revelation" - which he published along with the programmatic essay on demythologizing-Bultmann begins by discussing the general "question about God" that he states to be a necessary preunderstanding for the encounter with revelation. But then he transitions to asking what Christian faith makes of this general concept of God. His conclusion: "Human beings outside Christian faith are indeed unable to come to an answer [to the question about God]. . . . [Christian faith] claims that all answers outside the Christian answer are illusions." 5 Earlier, in I933, Bultmann stated his position more forcefully. In his essay on natural theology, he declares that "God is accessible only by faith responding to revelation. ... It therefore remains the case that all human speaking of God outside of faith speaks not of God but of the devil." 6 As he would in I957, Bultmann goes on in this essay to affirm that even unbelief is an acknowledgment of the "moment," but only in the sense that it acknowledges the question. And yet "the question is not the answer," and there is no way to move from question to answer apart from the power of God: "unbelieving existence

4. Part of the problem here is that Bultmann does not believe faith could ever exist at the level of preunderstanding. The category of Vorverständnis is a general ontological category, whereas faith belongs at the level of one's concrete ontic existence. So while it is true that Bultmann does not depict faith as "the existential preunderstanding necessary for making sense of the Bible" - since Bultmann could not possibly make sense of such an idea-it does not follow that he thereby does not make faith a necessary presupposition for the understanding of the Bible. To "make sense of the Bible," assuming that this is not merely to describe the general problem but to expound the Bible's unique answer, requires a faithful obedience to the message of God's revelation.

5. Idem, "Die Frage der natürlichen Offenbarung," in Glauben und Verstehen, 2:86. Unless otherwise stated, all emphasis is original. All translations are my own.

6. Idem, "Das Problem der 'natürlichen Theologie,'” in Glauben und Verstehen, I:303. 
is unable to change itself into believing existence."7 Unbelief is therefore disobedience, which is why Bultmann declares all attempts to understand God on the basis of our preunderstanding (that is, the "question" we bring to the text) to be, in fact, "sin." 8 This is precisely why Bultmann places strict limits on the usefulness of philosophy, because philosophical inquiry exists at the level of our preunderstanding; it helps to clarify the question, but in no way can it aid us in reaching the answer. The answer, as he puts it in his lectures on theological encyclopedia, comes through faith alone, which is the work of the Holy Spirit. 9 The answer, in fact, sheds light on the question itself, since "there is given to faith through revelation, through the gospel, a definitive 'clarification' of profane existence that is not visible to philosophy." Io Indeed, the question only becomes apparent as a genuine question concerned with authentic existence in light of revelation, a point that Bultmann makes in his reflections on the relation between law and gospel in Romans. ${ }^{\text {II }}$

The point is that when Bultmann identifies the question about God as a necessary preunderstanding for the text, or when he says that "the existential encounter with the text can lead to ... confessing faith as well as to outright unbelief," ${ }^{2}$ he is not claiming that one can understand the message of the Bible outside faith on the basis of our preunderstanding alone. The five theses in the 1957 essay on presuppositions are all prolegomena to the act of interpretation itself. In fact, the entire essay only seeks to achieve clarity regarding the necessity of presuppositions at the level of general hermeneutics. It does not exhaust Bultmann's understanding of theological hermeneutics. Moberly would have been well-served by focusing on Bultmann's I955 essay "Science and Existence" I3 as well as his 1955 Gifford Lectures, History and Eschatology. ${ }^{\mathrm{I}}$ Both of these writings turn from a

7. Ibid., I:304.

8. Idem, "Die Frage der natürlichen Offenbarung," in Glauben und Verstehen, 2:94.

9. Idem, Theologische Enzyklopädie (ed. Eberhard Jüngel and Klaus W. Müller; Tübingen: Mohr Siebeck, 1984), I42.

Io. Idem, "Die Geschichtlichkeit des Daseins und der Glaube: Antwort an Gerhardt Kuhlmann," ZTK n.s. II (1930): 353.

II. See idem, "Christus des Gesetzes Ende [1940]," in Glauben und Verstehen, 2:32-58. Bultmann insists that the knowledge of our sinfulness-being the essence of the "question" that the gospel alone "answers" - is "visible as such only from the standpoint of faith" (p. 35) and is only "visible on the basis of the grace that has actually appeared in Christ" (p. 4I). Furthermore, Rom 7 describes human beings without Christ "not . . . as they see themselves, but rather as they are seen from the standpoint of faith" (p. 45). According to Paul, "the natural buman being hates God without knowing it," and "this becomes apparent in the moment that the grace of God appears in Christ and is preached" (p. 47).

I2. Idem, "Ist voraussetzungslose Exegese möglich?" in Glauben und Verstehen, 3:I49; original emphasis removed.

13. Idem, "Wissenschaft und Existenz," in Glauben und Verstehen, 3:107-2I.

I4. Idem, History and Eschatology: The Gifford Lectures 1955 (Edinburgh: University of Edinburgh Press, 1957). 
general account of understanding as "existential encounter" to the specific kind of understanding proper to God's word in the kerygma, what Bultmann calls the new self-understanding (Selbstverständnis) of faith. In History and Eschatology, he places the material found in the 1957 theses within the chapters on "the essence of history." "I5 Preunderstanding and existential encounter are here located together as essential elements in any understanding of history. Bultmann follows this with a chapter on Christian faith and history, where he makes it clear that not just any existential encounter is required. To understand the Christian message one must have an eschatological encounter, that is, an encounter with Jesus Christ, wherein one receives the genuine freedom that "Christian faith believes . . . is presupposed for historical decisions," but which no one can have apart from God's gift. ${ }^{\mathrm{I}}$ If biblical interpretation is to be more than just historical-critical analysis - which, like philosophy in general, Bultmann consistently regards as only negatively relevant to Christian faith - then it must be a theological interpretation born from a living relation to Jesus Christ as the ground and object of faith. The eschatological self-understanding of faith may be the result of an existential encounter with Scripture, but it is also at the same time the presupposition for a genuine understanding of Scripture.

This hermeneutical relation between faith and the understanding of Scripture is first set forth by Bultmann in his I925 essay on theological exegesis, which is especially relevant to Moberly's article. The essay begins by opposing all ostensibly "neutral" methods of exegesis in light of the fact that the NT demands that one approach it from a posture of faithful obedience. New Testament exegesis is distinct from secular exegesis in that the exegete of the NT confronts the text's disruptive claim that "people do not have their existence at their disposal in such a way that they could pose the question of existence to themselves and possess the possibility of free action; all of that is given only to faith." 17 Theological exegesis requires not just any questioning of existence, but only a faithful or believing questioning. And yet this faithful questioning would seem to beg the question, for its presupposition (namely, faith) is also the goal, as the fourth of his 1957 theses indicates. The circularity of the exegetical task would therefore seem to be a serious problem. If one can only hear the word of the text in light of the questionableness of existence, and if this questionableness is only given in the word of the text, how is one able to hear and respond to the kerygma? Bultmann's answer might come as a surprise to those, like Moberly, who see him as an advocate of an individualistic act of

15. Ibid., IIO-37.

I6. Ibid., I50.

I7. Idem, "Das Problem einer theologischen Exegese des Neuen Testaments," in $A n$ fänge der dialektischen Theologie, vol. 2: Bultmann, Gogarten, Thurneysen (ed. Jürgen Moltmann; Munich: Kaiser, I963), 66. 
interpretation. He says that the "concrete situation" for exegesis of the NT is "the tradition of the church of the word." As the interpreter, I cannot stand outside my historical context, but in that "I stand in my existence in the tradition of the word, there is a readiness for faithful questioning." I8 In a rather remarkable move, given his reputation, Bultmann actually makes the community of faith the true presupposition for the interpretation of Scripture. Indeed, we can even say that, for Bultmann, the tradition of the church is the necessary preunderstanding for the hearing of God's wordprecisely the claim Moberly wishes to make over against Bultmann.

\section{"The Tradition Belongs to the Event Itself": Faith in Christ as Faith in the Church}

Let us now turn to Moberly's three objections to Bultmann, which I will treat in order. The first objection is that Bultmann "has a remarkably thin and undifferentiated understanding of what theological presuppositions might look like," so that he dismisses "dogma" while leaving his own theological presuppositions uninterrogated (p. 6). If this were really the case, then Moberly would be quite right in pointing out the "certain irony" of Bultmann's own theological assumptions (p. 7). But Bultmann nowhere dismisses theological axioms as such. In fact, in his theological encyclopedia, he appeals to the classic Lutheran dogma of the imputation of alien righteousness in support of his theological project. ${ }^{19}$ How are we to explain this? Moberly overlooks why Bultmann rejects dogma in his 1957 essay. It has nothing to do with a dismissal of the church and its tradition, as Moberly implies, which he chalks up to a modern German habit of denying ecclesial authority. He even cites Adolf von Harnack and William Wrede to illuminate Bultmann on this score. There is some truth in this, but just as much untruth. In actuality, Bultmann's dispute with dogma only concerns those teachings that compete with and are presumed always to overrule the results of historical research. The doctrine of Jesus' messianic self-identification is a problem because it concerns something that is, in principle, accessible to historical science. To presume the validity of such a doctrine over against the research is to objectify the divine as an object among other objects. God becomes a deus ex machina that trumps every other form of knowledge. The result is that faith becomes a sacrifice of the intellect (sacrificium intellectus). By contrast, the dogma of imputation is unproblematic because it is absolutely inaccessible to historical science (being a strictly divine act). Moreover, the doctrine frees the human person for engaging the questions of history, precisely because it denies that justification is to be found within the realm of immanent occurrences (that is,

I8. Ibid., 66-67.

19. Idem, Theologische Enzyklopädie, I40. 
the "works of the law"). The Christian is free to investigate history because she does not look to the phenomena of history as the source of her identity coram deo. It is worth noting that, for Bultmann, the doctrine of Christ's resurrection is a doctrine of the second kind.

Second, Moberly raises a complaint regarding the lack of attention to the character or virtue of the interpreter. Bultmann's account "is unduly abstract," he claims, because "it says too little about the situation of the returning reader who, having come to faith, now seeks to read and reread the biblical text in the light of that faith" (p. 8). We should begin by noting that this complaint is not uniquely applicable to Bultmann. The criticism has been lodged against Protestants ever since the Reformation, and it is a charge made with increasing frequency against, in particular, the dialectical school of theology, especially with the rising interest in virtue ethics. Consider the endless accusations of "christomonism" leveled against Barth's theology since its earliest days. Or consider John Webster's criticism that Eberhard Jüngel's emphasis on the indicative at the expense of the imperative "runs the risk of lacking substance," because of "a characteristically Lutheran suspicion of human sanctity as a possession or attribute of the believer rather than as that which is located in the holiness of Christ." 20 Indeed, it is characteristic of Lutheran theology, given the Formula of Concord's claim that "in spiritual and divine matters ... the human being is like a pillar of salt, like Lot's wife, indeed like a block of wood or a stone, like a lifeless statue." ${ }^{2 I}$ Dialectical theology is simply the systematic development of this Lutheran insight.

The reticence to think in terms of virtue and sanctification is thus evidence not of some modern existentialist blind spot in Bultmann, but rather of his fidelity to the magisterial Protestant tradition of the simul iustus et peccator. According to Barth, any lessening of this simul in favor of a distinction by degrees between the old person before and the new person later means that "one leaves the realm of the vita christiana as it is actually lived for a psychological myth without any material content." ${ }^{22}$ In short, we can readily admit that Moberly's observation is correct. Bultmann does not thematize the virtue or character of the reader in his hermeneutics. But in reply we must point out that he does so out of a concern to avoid any conflation of gospel and law. On the side of the gospel, Bultmann wishes to

20. John B. Webster, Eberhard Füngel: An Introduction to His Theology (Cambridge: Cambridge University Press, I986), I38-39.

2I. Formula of Concord, Solid Declaration 2.20, in The Book of Concord: The Confessions of the Evangelical Lutheran Church (ed. Robert Kolb and Timothy J. Wengert; Minneapolis: Fortress, 2000). The passage in question is culled from several of Martin Luther's own writings and is attributed to him as a quotation.

22. Karl Barth, Die kirchliche Dogmatik (4 vols.; Zürich: Evangelischer Verlag, I932-70), 4/2:647. 
protect its character as a sovereign act of divine grace that has no point of contact in the human person (including even in our moral psychology). On the side of the law, Bultmann wishes to protect its character as a contingent and situational divine command that does not become an abstract program for humanity as such, which would run roughshod over each person's particular historicity. Parenthetically, this is also why he refuses to incorporate specific political recommendations into theology-not at all because he thinks Christians should be apolitical, but because the political significance of the gospel becomes manifest anew in each moment. For this reason, "the church's task is to proclaim the word of God, not to pronounce political judgments. ... Theology must be sharply on guard against any identification of the Christian faith with a political program." ${ }^{23}$ Similarly, we must be on guard against any identification of the faith with a practical program of character formation. That is not to suggest such formation is irrelevant or unimportant, only that it cannot be the task of theology to state in advance what is particular to each person's historical situation.

This brings us, finally, to Moberly's third and central criticism of Bultmann: the absence of reflection on the church. Moberly's way of making this point is misguided. He begins by citing Bultmann's key argument from the 1957 essay for the necessity of hermeneutical translation, namely, the fact that the biblical texts "speak in a strange language with concepts of a faraway time, of a world-picture [Weltbild] that is strange to us." ${ }^{24}$ Moberly then wants to say that this statement only really applies if we ignore "a history of some 2,000 years of continuous interpretation and use," in which the Bible's language and concepts have been appropriated within the life of the church (p. Io). He further uses this statement as evidence for Bultmann's lack of attention to the church, since "knowledge of the ancient and enduring significance of the Bible ... was part of his education and formation from his earliest years; in important senses, its content was never 'alien' to him, whatever the problems of understanding it in relation to issues of modern thought and culture" (p. II). Bultmann, according to Moberly, takes for granted the significance of the Bible's message, because he takes the church for granted.

There are several layers of misunderstanding here that we must untangle. Let us begin with the most basic. First, Moberly's analysis of the original statement in Bultmann's 1957 essay fails to differentiate between the subject matter (die Sache) of Scripture and its cultural-historical form (inclusive of language, conceptuality, and world-picture). We see this in the sentences that immediately follow. Moberly speaks initially of a history "in which [the Bible's] language, concepts, and world picture have been

23. Rudolf Bultmann, "Theology for Freedom and Responsibility," Christian Century (August 27, 1958): 967-69; here, p. 969 .

24. Idem, "Ist voraussetzungslose Exegese möglich?" in Glauben und Verstehen, 3:I45. 
continuously appropriated in the life of the church," and then a few lines later, about how "the content of the NT was already significantly understood and appropriated within the life of the churches" (p. Io; emphasis added). Here the language of appropriation is applied equally to form and content. Moberly makes this conflation of form and content explicit when, at the end of this paragraph, he declares that "the extensive historic and contemporary ecclesial engagement with the content of the NT means that in important ways its subject matter and world view 25 are not 'alien'" (p. II). Moberly here and elsewhere assumes that Bultmann's statement regarding the strangeness of the biblical text pertains equally to "subject matter" and "world-picture," as if they occupy the same hermeneutical level. In truth, Bultmann's program of demythologizing begins by differentiating between the two. The kerygma (that is, the subject matter of the text) is permanently alien, because it is the scandal of the crucified Christ; the mythical world-picture becomes a false scandal when its historical strangeness is made necessary to the kerygma itself, in which case one is forced to believe not only the word of the gospel but also the cultural context within which this gospel originally took root (thereby effectively deifying that ancient cultural situation and rendering the gospel untranslatable into different cultural situations). This is why, in the 1957 essay, Bultmann precedes the quoted statement by describing the biblical texts as "witnesses to faith and proclamation" - faith and proclamation being key terms by which Bultmann names the kerygmatic Sache - and follows the statement by declaring, "Simply put: [the biblical writings] must be translated." ${ }^{26}$

25. It is crucial to preserve the strict distinction between Weltbild (world-picture) and Weltanschauung (world view). It is no exaggeration to say that Bultmann's entire project hangs on getting this distinction right. Unfortunately, the topic lies beyond the scope of this article. The following observations will have to suffice. First, the concepts of Weltbild and Weltanschauung, which Bultmann largely takes from Wilhelm Dilthey, conceptualize, respectively, (I) the cultural contexts of text and exegete, and (2) the philosophical formulation of one's Weltbild in the form of a static, universal system. A Christian Weltanschauung would therefore be the systematic conflation of the gospel with the cultural context of the theologian. Second, Bultmann locates Christian faith and theology over against and between the concepts of Weltbild and Weltanschaunng. That is, he believes faith demands that we differentiate the kerygma from every cultural Weltbild, ancient or modern, so as to prevent the ossification of the kerygma into a purportedly universal Weltanschaung, while at the same time faith demands that we closely interrogate each particular Weltbild so that we can responsibly translate the kerygma from its ancient context to our contemporary situation. Third, when translations of Bultmann use "world view" for "Weltbild," or when scholars assume that "world-picture" and "world view" mean the same thing, it can seem that Bultmann's statements about the need to reject the "mythical world-picture" of the Bible are in fact demanding a rejection of the theological content of the Bible. In fact, Bultmann is only criticizing the cultural form of the biblical text, not its kerygmatic content. This means that demythologizing is by no means a "liberal" theological program; it is in fact a supremely missiological program of intercultural and crosscultural dialogue. This is the subject of my dissertation, The Mission of Demythologizing: Rudolf Bultmann's Eschatological Dialectical Theology (Princeton Theological Seminary, 20I4).

26. Idem, "Ist voraussetzungslose Exegese möglich?" in Glauben und Verstehen, 3:I45. 
Second, and rather ironically, Moberly overlooks the fact that Bultmann's statement is a way of describing the problem that the church has continually wrestled with from the start. The whole history of allegorical and spiritual interpretation-arguably the most direct antecedent for Bultmann's hermeneutical program - is based on the premise that the language and concepts of the Bible belong to a foreign world-picture (that is, a foreign cultural context), and so "must be translated." It is especially ironic that Moberly places Augustine in conversation with Bultmann on this point, since Augustine's own interpretive strategies anticipate Bultmann's approach within modernity. See, for instance, Edmund Hill's notes to book I of Augustine's De Trinitate, where he makes the remarkable comment: "If one is going to interpret the eschatological images of scripture at all, to demythologize them, as the classical Christian tradition always has done, then with Augustine and this tradition, one must divinize them." 27 The differences between the exegetical strategies of Augustine and Bultmann notwithstanding, the point remains that Bultmann is expressing a judgment shared by Christians throughout the history of the church. Bultmann's statement does not ignore the appropriations of Scripture in the life of the church. It is in fact a description of the rationale behind those very appropriations. ${ }^{28}$

Third, and here we finally come to the heart of the matter, Bultmann's work evinces a longstanding engagement with the question of the church that Moberly seems to have overlooked. There are, of course, the writings directly about the church, such as his 1929 essay "Church and Teaching in the New Testament" and his 1955 essay, "The Transformation of the Selfunderstanding of the Church in the History of Early Christianity." 29 His magisterial two-volume Theology of the Nerw Testament opens and closes with extensive discussion of the church, not to mention the numerous ecclesiological comments that appear throughout the rest of the work. ${ }^{\circ}$ It is this latter document that also indicates a more important and subtle presence of ecclesiology in Bultmann's thinking. His NT theology famously begins with the statement, "Christian faith did not exist until there was a Christian

27. Saint Augustine, The Trinity (trans. Edmund Hill; Works of Saint Augustine I/5; Hyde Park, NY: New City Press, 199I), 96 n. 82.

28. In a 1953 essay on Christian eschatology, Bultmann explicitly connects his demythologizing program to a long history of theological interpretation, beginning with the very early years of the church and continuing through Augustine, Luther, Hegel, and Pietism. See Rudolf Bultmann, Die christliche Hoffnung und das Problem der Entmythologisierung (Stuttgart: Evangelisches Verlagswerk, 1954), 26-30.

29. See idem, "Kirche und Lehre im Neuen Testament," in Glauben und Verstehen, I:I5387; idem, "Die Wandlung des Selbstverstandnisses der Kirche in der Geschichte des Urchristentums," in Glauben und Verstehen, 3:13I-4I.

30. See especially idem, Theologie des Neuen Testaments (Tübingen: Mohr Siebeck, 1953), $\$ \$ 5-8$, IO-II, 5I-6I. 
kerygma, i.e., a kerygma that proclaims Jesus Christ as God's eschatological saving-act. ... This first occurred in the kerygma of the early churchcommunity, not in the proclamation of the historical Jesus." ${ }^{\mathrm{I}}$ Put simply, we cannot get behind the church to find some purportedly preecclesial Jesus, because our only access to Jesus is through the church's witness to him. Ecclesiology is included at all times within Christology. Kerygma is inseparable from the ecclesial community. In his final statement on the relation between the kerygma and the historical Jesus, Bultmann concludes with the axiomatic statement: "There is no faith in Christ which would not be at the same time faith in the church as the bearer of the kerygma, that is, in dogmatic terminology: faith in the Holy Spirit." ${ }^{2}$ Christology has what Hans Urs von Balthasar calls an "elliptical structure," in which content and form, or event and witness, are united. 33 It is what Paul Tillich describes as the unity of "historical fact" and "believing reception." 34 For Bultmann, therefore, the third article of the creed is included within the second article, not in the sense that the church is in itself the object of faith, but that faith recognizes the church as ingredient in its object.

More accurately, it is not so much the church that is included within the event of Jesus Christ but rather Christ himself who is present within the event of the church. This is, in fact, the very point Bultmann goes on to make in his 1960 address on the historical Jesus. "Faith in the church as the bearer of the kerygma" means that "Jesus Christ is present in the kerygma." This statement "presupposes that the kerygma is itself an eschatological occurrence; and it means that Jesus is actually present in the kerygma, that it is his word which meets the hearer in the kerygma." 35 As Bultmann puts it in his Theology of the New Testament, "Jesus himself speaks in the word of the church-community." ${ }^{6}$ It is for this reason that, in 1929, Bultmann says that the communication of the church "belongs itself to what is communicated," since it is not a "mere conveying" of facts but rather a word that addresses each person. 37 While it may come as a surprise to some, Bultmann affirms that the church's teaching "has the character of tradition, which belongs to the history that it narrates. The tradition belongs to the event itself." 38 The fact that ecclesial tradition is internal to the kerygmatic event of Christ's

3I. Ibid., I.

32. Idem, Das Verhältnis der urchristlichen Christusbotschaft zum historischen fesus (Heidelberg: Carl Winter, 1960), 26.

33. Hans Urs von Balthasar, Theo-Drama: Theological Dramatic Theory (trans. Graham Harrison; 5 vols.; San Francisco: Ignatius, 1988-98), 3:59.

34. Paul Tillich, Systematic Theology (3 vols.; Chicago: University of Chicago Press, I95I63), 2:98.

35. Bultmann, Verhältnis der urchristlichen Christusbotschaft zum historischen Fesus, 27.

36. Idem, Theologie des Neuen Testaments, 437.

37. Idem, "Kirche und Lehre im Neuen Testament," in Glauben und Verstehen, I:159-60.

38. Ibid., I:I6o. 
proclamation explains why the church can seem absent from Bultmann's theology. His theology is thoroughly kerygmatic and Christological, but precisely because it is so focused on Christ it is also at the same time focused on the ecclesial community as the bearer of God's word and the medium through which Christ speaks to us today. Bultmann's statement about the Gospel of John is thus equally valid as a statement about Bultmann himself and serves as a virtually direct response to Moberly's critique: "John himself does not make the concept of the church-community a theme as Paul does. The church-community is only spoken of indirectly. ... There is even lacking any specifically ecclesiological interest, any interest in cult and organization. But one may not conclude from this that interest in the church-community is completely absent. On the contrary, there is a very lively interest in it." 39

\section{"The Church Is Always a Missionary Church": Bultmann's Political Ecclesiology}

One might object that we are overly focusing on Bultmann's understanding of the early church, while Moberly's point has more to do with the contemporary church in which Bultmann lived and worked. Here again, though, we find Moberly's reading of Bultmann to be selective and misleading. He claims that, "when [Bultmann] touches on the social nature of knowledge, it is only family and nation, not church, that are mentioned as formative factors," which is a "lingering afterlife of a certain kind of Protestant Christian culture within the life of Germany" (p. 2I). He cites in support of his claim a passage from Bultmann's lectures in theology regarding the way "science and culture" are and must be determined by "the bond of human beings to their Volk." 40 Moberly criticizes Bultmann for not including the church alongside the "family and Volk-community." ${ }^{\mathrm{I}}$ What Moberly fails to see is that Bultmann is actually protecting the church as the community of faith in doing so, as we will see shortly. More unfortunately, Moberly adds in a footnote: "It is striking that Bultmann's emphasis on national community belongs to lectures delivered from 1926 to 1936 ,

39. Idem, Theologie des Neuen Testaments, 437.

40. Idem, Theologische Enzyklopädie, 40. The word Volk has no direct English equivalent. It refers generally to the nation understood as a particular cultural-biological people group. It is often best translated simply as "people" to preserve the layers of meaning. The word became a key symbol for the National Socialist ideology of "blood and soil," resulting in the rise of what came to be known as Volkstheologie, which was a theology that elevated "Germanism" into a theological norm. Moberly cites the English translation of Bultmann's lectures, which translates this phrase as "one's link to one's nation." Although this is not inaccurate, in this case it is crucial to recognize that Bultmann is addressing the ideology of the Volk that was prominent during this time. It also must be noted that this passage comes from the I 933 version of Bultmann's lectures. The significance of this will be noted in due course.

4I. Ibid. 
which received their written form in the context of National Socialism. Bultmann's membership of the Confessing Church did not apparently give him any appreciation of ecclesiology as potentially generative of a critique of certain common cultural assumptions" (p. 2I n. 42). Not only does Moberly miss the absolutely essential fact that this passage first appears in the 1933 lectures but he does not recognize that Bultmann is actually engaged in a direct criticism of National Socialist ideology. ${ }^{2}$

The true nature of Bultmann's comments becomes evident at the end of $\$ 9$ in his Theological Encyclopedia, where he deals with God's knowability in revelation. Much of this material restates in a different form the same point noted earlier regarding his position on natural theology. Like the I933 essay cited above (which was likely written concurrently with these lectures), Bultmann here affirms that we have a preunderstanding of revelation in the sense that we have a working concept of God that makes us existentially open to revelation, albeit unconsciously and unreflectively. But as in his other essays, Bultmann denies the ability of unbelief to speak of God and affirms the "radical impossibility of knowing God" apart from revelation. 43 He goes on to say that God cannot be known "from out of the situation," but only on the basis of the "special claim" and "special truth" of revelation that addresses us within a particular moment and illuminates the situation. 44 It is in this context that, in 1933, Bultmann then adds a short section about the danger of the "national movement," that is to say, "National Socialism." In a moment of remarkable boldness for a professor in Germany at this time, Bultmann declares that the Nazi movement's reaction to idealism has become "an ideology" that is in danger of "deteriorating into romanticism and materialistic biology." 45 The concrete reality of life - what people identify as the Volkstum - is "not a natural, biological factor," but it is given "only as historical [geschichtliche]." ${ }^{6} 6$ Someone hearing this in Bultmann's own day would have understood this to be a thoroughgoing rejection of Nazi ideology, and precisely on theological grounds. Bultmann everywhere understands history (Geschichte) as eschatology; eschatology is the truth of history, and history is only truly historical as eschatology. The two words function as synonyms from the perspective of faith.

To understand the full significance of this passage, we must place it in its larger historical context. On April 7, 1933, the civil service law was

42. Even in the context of talking about the bond to the nation, Bultmann adds a footnotes in which he says that "German ... cannot be a criterion" for what is right, because there are also "German abuses" (ibid., 4I n. 26). It may not seem so, but this is a courageous statement within Bultmann's context.

43. Ibid., 6r.

44. Ibid., 62-63.

45. Ibid., 64 .

46. Ibid., 64-65. 
passed with the so-called Aryan Paragraph, which stipulated that only those of Aryan descent could be employed in the public service. The university faculties of Erlangen and Marburg entered into a dispute over the Aryan Paragraph in the pages of Theologische Blätter. 47 Each side produced a report that explained its position. Marburg published its report in October 1933 , signed by the dean of the faculty, Hans von Soden, which declared that any denial of "the full unity between Jewish and non-Jewish Christians in the church" contradicted the witness of the apostles and reformers. $4^{8}$ The Erlangen report, written by Paul Althaus and Werner Elert, was published the following month. In sharp contrast to the Marburg statement, it differentiated between a "missionary church" (Missionskirche) and a "church-of-the-people" (Volkskirche). According to this report, the former is rightly concerned with proclaiming the gospel to new people groups, and it is this missionary context that one sees reflected in the NT rejection of a separation between Jews and Gentiles. The latter, however, is the current situation of the church in its institutional and state-recognized form, and in this context it is legitimate to insist on what the authors of this report call "its special biological-historical position." The task of the church, according to Althaus and Elert, is "to be the Volkskirche of the German people." 49

The following month, Rudolf Bultmann intervened in the debate. He had already helped draft the Marburg statement, but in the December issue he presented his own position. The key paragraph occurs when Bultmann responds directly to the distinction between a Missionskirche and Volkskirche:

The fact is that the New Testament knows not a single word requiring the binding of the ecclesiastical office to a certain ethnicity. The Erlangen report says, however, that the New Testament only draws this conclusion for a missionary church. Where a missionary church has become a Volkskirche, there the issue of ethnicity must be required for the ecclesiastical office. If this thesis is meant to be taken as a basic principle, then it is to be absolutely rejected. When compared to the Volk as a worldly historical entity whose dimensions are constituted by biological factors, the church is always a missionary church. It never becomes a piece of the world, but rather always maintains its

47. The documents related to that dispute are available in Heinz Liebing, ed., Die Marburger Theologen und der Arierparagraph in der Kirche: Eine Sammlung von Texten aus den Fabren 1933 und 1934 (Marburg: Elwert, 1977).

48. Hans von Soden, "Gutachten der Theologischen Fakultät der Universität Marburg zum Kirchengesetz über die Rechtsverhältnisse der Geistlichen und Kirchenbeamten," TBl I2 (I933): 289-94, here, p. 293; original emphasis removed.

49. Paul Althaus and Werner Elert, "Theologisches Gutachten über die Zulassung von Christen jüdischer Herkunft zu den Aemtern der deutschen evangelischen Kirche," $T B l$ I2 (1933): 32I-24, here, p. 323 . 
transcendent, eschatological dimension. The preaching of the gospel always rings out to the Volk, never from the Volk. $5^{\circ}$

Bultmann's remarkable statement in this piece illuminates his theological lectures from that same year. By refraining from putting the church alongside family and Volk-community, he was actually preserving the insight that the church is always a missionary church, always an eschatological reality. Or, as he would later put it, the church is included in the event of the kerygma. It does not stand alongside the other cultural factors in the world as one social influence among many. The church, if it is indeed the place where God speaks to us, is the site where the gospel "rings out to the Volk, never from the Volk." ${ }^{1}$ Contrary to Moberly's assessment, Bultmann could hardly have given a stronger critique of "common cultural assumptions." Bultmann does not ignore the church in the least. On the contrary, his theology demonstrates a "very lively interest in it," to quote his own words about John. And when the truth of the gospel was on the line, as it was in the Kirchenkampf, Bultmann's words could ring out with prophetic power.

\section{The Rule of Faith and the Translatability of THE Gospel: Learning From BultmanN}

Although we have corrected Moberly's reading, it cannot be stressed enough that his portrayal of Bultmann is still significantly more appreciative than the vast majority of Anglophone discussions of the great Marburger. That only goes to show just how far the scholarly world still has to go in order to truly appreciate the life and legacy of Rudolf Bultmann. Toward that end, what follows will explore what significance such appreciation might have for both church and academy.

In responding to Moberly, we have made the following observations: (I) Bultmann's account of preunderstanding does not open the door to any kind of natural theology but always remains in service of a genuinely theological hermeneutics. (2) Bultmann embraces traditional dogmas within the parameters of historical inquiry and under the proviso that one can differentiate their indispensable theological judgments from their dispensable cultural-philosophical form. (3) He refuses to thematize in advance the virtue of the interpreter along with any other factor that could threaten the freedom of God to encounter people in new and unanticipatable ways through a sovereign act of justifying grace. (4) His understanding of the relation between Christ and community means that the church and its traditions are always included within the kerygma and are thus invisibly and

50. Rudolf Bultmann, "Der Arier-Paragraph im Raume der Kirche," TBl I2 (1933): 35970 , here, p. 365 .

5I. Moberly's line of inquiry, if not framed in just the right way, runs the risk of inverting this relation between gospel and Volk. 
indirectly the subject of theological inquiry. Finally, (5) Bultmann's entire theological and hermeneutical program serves the ongoing mission of the church in the midst of great sociopolitical challenges. ${ }^{2}$ Each point represents an aspect of Bultmann's thought that has been frequently ignored or misunderstood. Moreover, these observations are not disconnected issues in his theology; they are all, in fact, closely interrelated. Examining this interrelation will help illuminate the continuing relevance of Bultmann for contemporary work in theological interpretation.

As a Lutheran dialectical theologian, Bultmann's starting point is the free act of God's justifying grace, conceptualized dogmatically in the doctrine of the imputation of Christ's alien righteousness. God must be a wholly other God if the saving word of the gospel is to be truly a word of grace. And God's gracious action, if it is to be truly free and truly divine, must be an event that is new every morning. It cannot become an object or datum within the immanent realm of phenomenal occurrences. Grace is an "eschatological event" that comes to us out of and orients us toward the coming future of God. The saving work of God in Christ is therefore intrinsically dialectical and necessitates differentiations between law and gospel, time and eternity, immanence and transcendence, myth and kerygma, world and God. This understanding of grace as an event is, as we have already noted, the reason Bultmann does not thematize the virtue or disposition of the interpreter. It is also why he rejects the emphasis on "feeling" (Gefühl) and "experience" (Erlebnis) in Friedrich Schleiermacher and Wilhelm Herrmann, respectively, and why he opposes the historicism of Ernst Troeltsch and the questers for the historical Jesus. His eschatological understanding of God and the gospel is the basis for his missionary account of the church as well as his opposition to natural theology. It is what funded his courageous opposition to German Christian ideology. Most importantly for our purposes, it is the basis for his distinction between the kerygmatic norm and its cultural-historical form. Bultmann understands the kerygma to be, in essence, the creaturely vehicle of this divine event of grace; in fact, it simply is the event itself, insofar as it is heard and obeyed in faith. Paradoxically, the kerygma is simultaneously divine and human, a single divine-human event of proclamation that justifies the sinful hearer.

52. A full analysis of the political nature of Bultmann's demythologizing program will be the subject of future articles. For now, it will suffice to point to Hammann's keen judgment that demythologizing was "a theological dispute with current myths" (Rudolf Bultmann, 309). A number of other scholars argue that the "current myth" in question is Alfred Rosenberg's "myth of the twentieth century." See especially Wichmann von Meding, "Rudolf Bultmanns Widerstand gegen die Mythologisierung der christlichen Verkündigung," TZ 53 (I997): I95215 , esp. pp. 2OI-6. It is worth remembering that Bultmann gave his programmatic lecture (the so-called Entmythologisierungsvortrag) at a meeting of the Gesellschaft für evangelische Theologie (Society for Protestant Theology), which was a group of scholars in the Confessing Church who gathered to respond to the problem of National Socialism. Bultmann sought to provide nothing less than the hermeneutical foundation for engaging in the Kirchenkampf. 
This further means that the kerygma has to be differentiated from every theological conceptualization or objectification of it (for example, myths, creeds, and doctrines), because those conceptualizations are cultural phenomena that can, at best, only bear witness to the event within a particular time and place, within a specific historical situation or Weltbild. 53 And although the kerygma necessarily takes a particular cultural-historical form, that form is never essential to the kerygma itself and is always subject to critical interrogation. The kerygma is always open to new situations and new conceptualities. Or as Bultmann would say, the kerygma has to be translated. What we have here described is the program of demythologizing - a program whose logic is not determined by modernity but by the gospel itself. 54 "Demythologizing is a demand of faith itself," Bultmann writes in 1952 , in that faith "insists on the liberation from bondage to every worldpicture that objectifying thinking conceptualizes, whether it is the thinking of myth or the thinking of science." 55

Assuming scholars come to appreciate the true nature of Bultmann's theology and hermeneutics - shorn of the misunderstandings regarding his relation to philosophy and existentialism - what might be the implications for the project of theological interpretation? In the space remaining, I will highlight just one of many. Central to the rise of theological interpretation of Scripture has been the scholarly rebellion against a purportedly "neutral" exegesis defined exclusively by the historical-critical method and famously codified by Krister Stendahl in terms of the two "tenses" of meaning in the biblical text: "what did it mean?" and "what does it mean?"56 According

53. Although we cannot explore the point at length here, it is essential to understand that Bultmann defines myth as a form of objectifying thinking within an ancient cultural Weltbild. In other words, myth names a contextual conceptualization of the theological norm of the kerygma, specifically, a context in which we no longer live with assumptions we no longer share.

54. For a defense of this claim, see Eberhard Jüngel, "Die Wahrheit des Mythos und die Notwendigkeit der Entmythologisierung [1990]," in Indikative der Gnade-Imperative der Freiheit (Tübingen: Mohr Siebeck, 2000), 40-57.

55. Rudolf Bultmann, "Zum Problem der Entmythologisierung," in Kerygma und Mythos, vol. 2: Diskussion und Stimmen zum Problem der Entmythologisierung (ed. Hans-Werner Bartsch; Hamburg: Reich, 1952), 207. Bultmann goes on to say: "In fact, radical demythologizing is the parallel to the Pauline-Lutheran doctrine of justification through faith alone without the works of the law. Or, rather, it is the consistent application of this doctrine to the field of knowledge. Like the doctrine of justification, it destroys every false security and every false demand of human beings for security, whether the security is grounded on our good action or on our established knowledge. Those who would believe in God as their God need to know that they have nothing in hand on the basis of which they could believe, that they are poised, so to speak, in midair and cannot request any proof of the truth of the word that addresses them. For the ground and object of faith are identical. They alone find security who let all security go, who-to speak with Luther-are ready to enter into inner darkness" (ibid.).

56. Krister Stendahl, "Biblical Theology, Contemporary," in IDB I:418-32, here, p. 419. It is worth noting that Stendahl frames his position in opposition to Barth and Bultmann, and in fact Bultmann's definitive rejection of Stendahl's two-step approach appeared seven years before the latter's article in his I955 essay "Wissenschaft und Existenz." 
to Stendahl, biblical theology concerns itself strictly with the former question, while theology is concerned with the latter. The fully justified rebellion against this two-step hermeneutic has involved, among other things, an appreciation for the utility (and even necessity) of theological presuppositions, hence Moberly's appreciation for Bultmann's rigorous emphasis on the necessity of hermeneutical presuppositions and the impossibility of neutral exegesis. The key theological presupposition for most of those involved in the theological exegesis conversation is the "Rule of Faith" (regula fidei), which refers to the theological norms conceptualized and codified in the ecumenical creeds. 57 The complete bracketing off of such norms and presuppositions is not only methodologically unsound and theologically suspect, but also practically impossible. There are, of course, numerous ways to abuse this appeal to the regula fidei, and Joel Green helpfully identifies five criteria for properly relating canon and creed..$^{8}$ But there is often a lack of critical scrutiny regarding the very idea of a dogmatic "rule" for biblical interpretation, and it is precisely at this point that Bultmann may have something to offer to current theological exegetes.

Appeals to the regula fidei, much like appeals to the plain sense of Scripture itself, are often in danger of failing to interrogate the cultural-historical presuppositions behind these purportedly universal statements of Christian faith. The creedal formulas are given a binding status in a way that makes the cultural assumptions of their authors binding for Christians today. This effectively baptizes a certain Platonic or neo-Platonic philosophical conceptuality as ingredient in the gospel itself. Unless we are willing to make the claim - as many Christians do-that God could only have become incarnate in a particular time and place, and that the mythical-cultural assumptions and philosophical conceptualities of the ancient Hellenistic world were themselves "assumed" in the incarnation along with human flesh, 59 then we must be able to differentiate between the theological norms enshrined in Scripture and the creeds from the historically bound notions that were used by the prophets, apostles, and church doctors to conceptualize these norms for their local communities of faith. ${ }^{60}$ To identify the

57. See Daniel J. Treier, Introducing Theological Interpretation of Scripture: Recovering a Christian Practice (Grand Rapids: Baker Academic, 2008), 57-77; Joel B. Green, Practicing Theological Interpretation: Engaging Biblical Texts for Faith and Formation (Grand Rapids: Baker Academic, 20II), 7I-98.

58. Ibid., $77-82$.

59. This is, in fact, precisely the claim that Helmut Thielicke made in his response to Bultmann ("Die Frage der Entmythologisierung des Neuen Testaments [1942]," in Kerygma und Mythos, vol. I: Ein theologisches Gespräch [ed. Hans Werner Bartsch; 3rd ed.; Hamburg: Reich, 1954], 159-89).

6o. As an example, Green discusses the Chalcedonian and Athanasian claim that Jesus is composed "of a rational soul and human flesh," a claim that presupposes a Platonic anthropology. Green identifies the theological norm latent within it, namely, "that Fesus is fully a buman being" (Practicing Theological Interpretation, 92). 
theological norm - that is to say, the kerygmatic event-in distinction from its contextual form is to identify the possibility and necessity of translating this norm into a new contextual form-a possibility and necessity that, as missiologists have repeatedly pointed out, follows from the nature of the incarnation itself as a divine act of self-translation. ${ }^{6}$ If the kerygmatic message is "without a revealed language or a founding original culture," then "all cultural forms that distinguish and define human life and experience are in principle worthy of bearing the truth of Christianity." ${ }_{2}$ Those who are at home in one particular cultural context-in this case, let us say the philosophical contexts of either the ancient or reformational creedal traditions-must therefore develop a theological hermeneutic commensurate with the fact that the kerygma cannot be confined or conflated with the assumptions of their particular situation, even if those assumptions are internal to the canonical Scriptures or the ecumenical "Rule of Faith." The name that Bultmann gives to this hermeneutic is demythologizing: a differentiation of the kerygma from, among other things, the mythical Platonic concepts employed in the past for the sake of the ongoing translations of the kerygma into new conceptualities today. ${ }^{6}$ Put simply, demythologizing is a missional or intercultural hermeneutic.

If there is anything theological exegetes can learn from Bultmann, it is his uncompromising fidelity to a transcultural truth that nevertheless always takes a particular cultural form, while remaining available for ever new forms tomorrow. He anticipated missiological insights within his hermeneutical program long before the intersection of missiology and hermeneutics entered the theological academy. For Bultmann, every act of interpretation is an act of translation, and as Theo Sundermeier puts it, "every translation of the gospel is a form of inculturation." 64 Translation is "not the transporting of cargo unchanged from one shore to another. New

6r. The most well-known articulation of this claim in English is found in Andrew F. Walls, "The Translation Principle in Christian History [1990]," in The Missionary Movement in Christian History: Studies in the Transmission of Faith (Maryknoll, NY: Orbis, 1996), 26-42, here, pp. 27-28. Also relevant is his essay "The Gospel as Prisoner and Liberator of Culture," in ibid., 3-15. This essay argues against the notion of a single "historic Christian faith" in light of the plurality of historical forms that Christianity has taken over the centuries.

62. Lamin Sanneh, Translating the Message: The Missionary Impact on Culture (2nd ed.; Maryknoll, NY: Orbis, 2008), 74.

63. For an explicit example of Bultmann's critical inquiry into the received dogmatic tradition, see his lecture on the Christological confession of the World Council of Churches given in Aarau in February 1951. This essay is unique in that it represents one of the few instances in which Bultmann engages contemporary ecclesial-confessional questions. One line from his essay, in particular, encapsulates several of the key themes of this article: "Just as the $\dot{\varepsilon} \kappa \kappa \lambda \eta \sigma i \alpha$, the church, the eschatological community, is only ever really $\dot{\varepsilon} \kappa \kappa \lambda \eta \sigma i \alpha$ as an event, so also Christ's lordship, his deity, is always only ever an event" ("Das Christologische Bekenntnis des Ökumenischen Rates," in Glauben und Verstehen, 2:246-6I, here, p. 258).

64. Theo Sundermeier, Mission-Geschenk der Freibeit: Bausteine für eine Theologie der Mission (Frankfurt am Main: Lembeck, 2005), 77 n. I. 
pictures, new idioms, new comparisons must be found, which transfer the subject matter in such a way that it can be received on the other shore." 65 Biblical interpreters, like missionaries past and present, must learn that all interpretation, all mission, is about their own conversion to the infinite and unanticipatable translatability of the gospel. ${ }^{66}$ Theological exegetes must, as Bultmann says, "let all security go" and, with Luther, prepare "to enter into inner darkness." ${ }^{67}$ This inner darkness is a space of freedom for the future that coincides with a freedom from the past - not a freedom from tradition as such, but a freedom from the temptation to establish any tradition as a permanently or universally binding rule for biblical interpretation.

Demythologizing, as a theological hermeneutic of intercultural understanding and translation, is a program for interpreting Scripture without security in our cultural contexts but in complete fidelity to God's future. Although it presents a radical challenge to every tradition that would claim a normative status, it does so for the sake of the liberating work of the Spirit, who guides the followers of Jesus "into all the truth" (John I6:13) precisely through the pluralism of Pentecost (Acts 2:I-I3). A demythologizing hermeneutic is therefore an emancipatory hermeneutic that creates a pentecostal space of interpretive freedom for new possibilities of mutual understanding and transcultural hybridity.

In closing, we should note again the rationale for Bultmann's program. He delivered his lecture at a time when church and national leaders were explicitly conflating the norm of the gospel with the context of German culture ("blood and soil"). Bultmann realized it was inconsistent for theologians in the Confessing Church to criticize the confusion of gospel and culture in their present-day context if they were not similarly critical of the confusion of gospel and culture in past contexts, including the context of the NT itself. Bultmann's hermeneutical program therefore indirectly criticizes modern Nazi mythology by directly interrogating the theological error at its root. The question for theological interpretation today is whether it has a hermeneutical approach that is sufficiently critical of the conflation between kerygma and context, that is to say, sufficiently attuned to the way our relation to the sociocultural contexts of canon and creed has implications for our relation to the present context.

65. Ibid., 85 .

66. See Sanneh, Translating the Message, 29: "As missionaries of the modern era found, encountering evidence of God's reality outside the familiar terms of one's culture overthrows reliance on that culture as universal and exclusive. A fresh criterion of discernment is introduced by which the truth of the gospel is unscrambled from one cultural yoke in order to take firm hold in another culture. Contrary to much of the conventional wisdom in this field of study, mission implies less a judgment on the cultural heritage of the convert (although in time the gospel will do the winnowing) than on that of the missionary."

67. Bultmann, "Zum Problem der Entmythologisierung," 207. 
Put another way, is theological interpretation adequately attuned to the problem of mission and translation? Is the appeal to a regula fidei consistent with a kerygma that cannot be circumscribed within any context, past or present? Does theological interpretation have the resources to oppose the "cultural captivity of the gospel"? 68 With respect to these and other questions, the work of Rudolf Bultmann lays the foundation for responsibly engaging these issues with clarity and integrity.

68. Sanneh, Translating the Message, 92. 
